\title{
Tinjauan Hukum Tentang Penataan Pendistribusian Gas Elpiji 3 Kilogram Pada Pangkalan Gas Elpiji di Kabupaten Cianjur
}

\author{
Hesti Dwi Astuti*) dan Rizky Wulan Juliani**) \\ Fakultas Hukum Universitas Suryakancana Cianjur \\ Email: * hestidwiastutilabiba@yahoo.com, ${ }^{* *}$ rizkywulanjuliani10@gmail.com
}

\section{Info Artikel:}

Diterima: 25 Januari 2018 | IDisetujui: 28 Maret $2018 \quad$ |Dipublikasikan: 31 Maret 2018

Kata Kunci:

Distribusi; Ekonomi:

Konsumen; Pertamina.

\begin{abstract}
Abstrak
Globalisasi ekonomi dan perdagangan bebas, mendominasi berbagai aktivitas bisnis (barang/jasa) manusia dewasa ini. Salah satunya adalah perihal pendistribusian gas LPG. Prosedur pelaksanaan pendistribusian gas elpiji yaitu: terdapat proses pendistribusian dengan cara memanfaatkan teknologi sistem informasi yang bertujuan untuk mendapatkan informasi kemana saja gas elpiji tersebut didistribusikan oleh agen, daerah mana saja yang mengkonsumsi gas elpiji tersebut dan berapa jumlahnya sehingga pertamina dapat mengetahui kebutuhan pasokan gas elpiji pada setiap agen di wilayah tersebut, yang pada akhirnya diharapkan proses pendistribusian gas akan lebih cepat, akurat, agen dapat bekerja secara baik, efektif, dan efisien. Selain itu adapun yang menjadi kendala saat pendistribusian gas elpiji, yaitu saluran distribusi ini harus benar-benar dipertimbangkan, dalam hal ini perusahaan atau produsen harus memperhatikan kendala yang dihadapi dalam pendistribusian gas elpiji, diantaranya: terdapat kendala pengiriman karena kurang lancarnya lalu lintas, dan harus mengikuti prosedur yang berlaku saat pengambilan gas elpiji, seperti mengikuti antrian.
\end{abstract}

Keywords: Agent; Distribution; The Economy; Consumer; Pertamina.

\begin{abstract}
Economic globalization and free trade, dominates a wide range of business activities (goods/ services) this adult human. One of them is about the distribution of LPG gas. LPG gas distribution implementation procedures, namely: there is a process of distribution by way of utilizing the technology information system that aims to acquire information wherever the LPG gas distributed by the Agency, the area where only consume the LPG gas and how much the amount so that pertamina can know LPG gas supply needs at any dealer in the area, which is ultimately expected to process gas distribution will more quickly, accurately, agents can works very good, effective, and efficient. In addition as for the time constraints that become distribution LPG gas, namely, distribution channels, this should really be taken into consideration, in this case the company or manufacturer should pay attention to obstacles faced in distributing gas $L P G$, among them: there are constraints due to lack of lancarnya shipping traffic, and should follow the current procedures LPG gas retrieval, such as following the queue.
\end{abstract}




\section{A. PENDAHULUAN}

Globalisasi ekonomi dan perdagangan bebas, mendominasi berbagai aktivitas bisnis (barang/jasa) manusia dewasa ini. Kegiatan bisnis dilakukan manusia di desa-kota-dunia, anak-dewasa, miskin-kaya, pendidikan rendah-tinggi, formal-informal, yang kesemuanya bertujuan untuk mencari keuntungan yang tidak ada lain diperoleh dari hasil penjualan barang/ jasa kepada konsumen. ${ }^{1}$ Dalam literatur ekonomi, kelompok pertama disebut sebagai pengusaha atau pelaku usaha. Semua pelaku usaha adalah konsumen, sebaliknya tidak semua konsumen adalah pelaku usaha, sehingga masalahmasalah yang dihadapi oleh konsumen adalah menyangkut semua lapisan dan golongan masyarakat yang perlu mendapat perhatian Dewan. ${ }^{2}$

Liquefied Petroleum Gas (LPG) PERTAMINA dengan brand ELPIJI, merupakan gas hasil produksi dari kilang minyak (kilang BBM) dan kilang gas, yang komponen utamanya adalah gas propana $(\mathrm{C} 3 \mathrm{H} 8)$ dan butana $(\mathrm{C} 4 \mathrm{H} 10)$ lebih kurang 99\% (sembilan puluh sembilan persen) dan selebihnya adalah gas pentana ( $\mathrm{C} 5 \mathrm{H} 12)$ yang dicairkan. Dalam surat Keputusan Bupati Cianjur Nomor 541.11/Kep.298-Perindag/2014 tentang penetapan harga jual eceran tertinggi Liquified Petroleum Gas, tabung ukuran $3 \mathrm{~kg}$ (tiga kilogram) untuk keperluan rumah tangga dan usaha mikro di Kabupaten Cianjur telah ditetapkan dan terlampir mengenai Harga Eceran Tertinggi (HET) gas elpiji $3 \mathrm{~kg}$ (tiga kilogram) sesuai dengan jangkauan jarak dan kondisi jalan per kecamatan dalam pendistribusian LPG dari Agen ke Pangkalan di Wilayah Kabupaten Cianjur. ${ }^{3}$ Maka sesuai peraturan yang sudah ditetapkan Kecamatan Cianjur memiliki Harga Eceran Tertinggi (HET) pada Pangkalan Rp. 16.000,- (enam belas ribu rupiah) sedangkan Agen Rp. 14.500,(empat belas ribu lima ratus rupiah). Namun demikian meskipun telah ada peraturan mengenai HET (Harga Eceran Tertinggi) banyak Pangkalan-pangkalan yang menjual melebihi dari HET (Harga Eceran Tertinggi) yang ditentukan, ini adalah masalah yang terjadi pada pendistribusian gas elpiji di kabupaten Cianjur, tidak sesuai dengan apa yang dijanjikan kepada masyarakat agar masyarakat mendapatkan kesejahteraan, dalam hal ini tidak adanya keadilan antara masyarakat selaku konsumen dan pelaku usaha. Dalam teori keadilan menurut Aristoteles "yang sangat penting dari pandangannya

\footnotetext{
Firman Tumantara Endipradja, Hukum Perlindungan Konsumen (Filosofi Perlindungan Konsumen dalam Perspektif Politik Hukum Negara Kesejahteraan) (Malang: Strata Pers, 2016), hlm. 4.

2 Surat Pengusul DPR RI Nomor: 05/LEGNAS/KES.BANG/XI/98 tanggal 20 November 1998.

Keputusan Bupati Cianjur Nomor: 541.11/Kep.298-Perindag/2014.
} 
ialah pendapat bahwa keadilan mesti dipahami dalam pengertian kesamaan". ${ }^{4}$

Saat ini gas elpiji $3 \mathrm{~kg}$ (tiga kilogram) merupakan barang yang paling dicari oleh masyarakat khususnya ibu rumah tangga sejak konversi minyak tanah ke gas. Gas elpiji 3 kg (tiga kilogram) sudah menjadi kebutuhan pokok yang sulit tergantikan dengan yang lain salah satu alasannya karena harganya yang disubsidi oleh Pemerintah sehingga harga yang sampai ketangan konsumen lebih murah dibandingkan dengan gas elpiji yang ukuran $12 \mathrm{~kg}$ (dua belas kilogram). Tidak seperti barang kebutuhan pokok lainnya yang berasal dari banyak produsen khusus untuk gas elpiji $3 \mathrm{~kg}$ (tiga kilogram) distribusinya diatur oleh Pertamina. Masalah lain yang sering muncul yaitu kelangkaan gas elpiji $3 \mathrm{~kg}$ (tiga kilogram), meskipun pasokan gas dari agen tetap ada namun karena stoknya terbatas tidak semua pengecer kebagian. Dari kelangkaan tersebut, di sinilah terjadi banyak kecurangan harga penjualan dari sub agen (pangkalan) dengan menjual melebihi dari HET (Harga Eceran Tertinggi) yang sudah ditentukan.

Namun demikian meskipun telah ada peraturan mengenai penetapan harga jual eceran tertinggi, pada kenyataannya di lapangan atau dalam proses pelaksanaannya masih sering ditemukan masalah. Adapun masalah yang timbul dalam hal ini untuk mendapatkan keuntungan yang lebih bagi sub agen (pangkalan). Menyikapi masalah tersebut, Pemerintah dan yang bersangkutan dalam hal ini terutama Hiswana Migas Cianjur, dan Agen mengupayakan solusi dari masalah tersebut di atas dengan cara memberikan surat peringatan terhadap sub agen, ataupun mengadakan sosialisasisosialisasi yang bertujuan untuk menyelesaikan dan mencari jalan keluar terhadap masalah-masalah yang terjadi di lapangan.

\section{B. METODE PENELITIAN}

Penelitian ini adalah Yuridis Normatif, yang mengungkapkan dan mengkaji berbagai perangkat hukum yang mengatur tentang pendistribusian gas elpiji, yang diatur dalam Keputusan Bupati Cianjur Nomor 541.11/Kep.298Perindag/2014 tentang Perubahan Kedua atas Keputusan Bupati Cianjur Nomor 541.11/Kep.124-PE/2012 Tentang Penetapan Harga Jual Eceran Tertinggi Liquified Petroleum Gas Tabung Ukuran $3 \mathrm{Kg}$ (tiga kilogram) Untuk Keperluan Rumah Tangga dan Usaha Mikro di Kabupaten Cianjur. Adapun prosedur

4 Muhammad Syukri Albani Nasution, dkk, Hukum Dalam Pendekatan Filsafat (Jakarta: Kencana Prenada Media Group, 2016), hlm. 315. 
penelitian ini menggunakan spesifikasi penelitian deskriptif analisis, teknik pengumpulan data dilakukan dengan cara penelitian kepustakaan dan penelitian lapangan dan analisis data dilakukan secara kualitatif.

\section{PEMBAHASAN}

\section{Pendistribusian Gas Elpiji}

Distribusi adalah suatu proses penyampaian barang atau jasa dari produsen ke konsumen dan para pemakai, sewaktu dan dimana barang atau jasa tersebut diperlukan. Proses distribusi tersebut pada dasarnya menciptakan faedah (utility) waktu, tempat, dan pengalihan hak milik. ${ }^{5}$ American Marketing Association (AMA) mendefinisikan bahwa saluran distribusi merupakan suatu struktur yaitu organisasi dalam perusahaan, baik dari dalam perusahaan maupun dari luar perusahaan yang terdiri dari pedagang besar/distributor, agen dan pengecer, ${ }^{6}$ melalui sebuah komoditi, produk atau jasa dipasarkan. ${ }^{7}$ Alma mengungkapkan distribusi merupakan sekumpulan lembaga yang saling terhubung antara satu dengan lainnya untuk melakukan kegiatan penyaluran barang atau jasa sehingga tersedia untuk dipergunakan oleh para konsumen (pembeli). ${ }^{8}$ Sedangkan Daniel mengungkapkan distribusi merupakan suatu kegiatan dari sebuah organisasi yang bertujuan untuk memperlancar kegiatan penyaluran barang atau jasa dari produsen ke konsumen. ${ }^{9}$ Hal lain diungkapkan oleh Tjiptono bahwa distribusi adalah kegiatan pemasaran yang berusaha memperlancar dan mempermudah penyampaian barang dan jasa dari produsen kepada konsumen, sehingga penggunaannya sesuai yang diperlukan (jenis, jumlah, harga, tempat, dan saat dibutuhkan). ${ }^{10}$

Dalam perkembangannya, konsep awal distribusi telah berevolusi dari physical distribution management menjadi logistic management dan selanjutnya berkembang menjadi supply chain management. ${ }^{11}$ Dalam hal distribusi, ada dua sisi yang berperan, yakni produsen dan konsumen. Produsen sebagai sisi prinsipal berperan supaya suatu produk

\footnotetext{
Saladdin Wirawan Efendi, "Analisis Usaha Bisnis Distribusi Gas Elpiji 3 Kg," Jurnal STIM Amkop (Palembang 2012).

6 Mikael Hang Suryanto, Sistem Operasional Manajemen Distribusi (Jakarta: Grasindo, 2016), hlm. 4.

7 David Sukardi Kodrat, Manajemen Distribusi... loc.cit.

8 Edy Purnomo, Pengertian Distribusi Secara Umum dan Menurut Para Ahli, https://vauzidotnet.wordpress. com/2014/03/07/pengertian-distribusi-secara-umum-dan-menurut-para-ahli/, 2014.

$9 \quad$ Edy Purnomo, Pengertian Distribusi Secara... loc.cit.

10 Yuni Minar Novata, "Distribusi Untuk Kegiatan Usaha," Jurnal Politeknik (Bandung 2014).

11 Gattorna, J.L. dan Walter, D.W., dalam Mikael, Managing the Supply Chain: A Strategic Perspective, (London: Mamillan Press, 1996), hlm. 5.
} 
dapat tersebar secara merata. Sementara pada sisi konsumen adalah bagaimana mereka sebagai pemakai produk dapat memperoleh produk itu dengan mudah. Kedua sisi tersebut bertemu pada titik temu, yaitu faktor kedekatan dan kemudahan.

Fungsi saluran distribusi adalah aktivitas-aktivitas yang dilaksanakan anggota saluran distribusi untuk memindahkan barang dari produsen ke konsumen yang pada pelaksanaannya dapat menimbulkan perbedaan aliran barang dari principal hingga konsumen. ${ }^{12}$ Menurut UU No. 5 Tahun 1999 tentang Larangan Praktek Monopoli dan Persaingan Usaha Tidak Sehat menentukan pengertian "pelaku usaha adalah setiap orang perorangan atau badan usaha, baik yang berbentuk badan hukum atau bukan badan hukum yang didirikan dan berkedudukan atau melakukan kegiatan dalam wilayah hukum negara Republik Indonesia, baik sendiri maupun bersama-sama, melalui perjanjian, menyelenggarakan berbagai kegiatan usaha dalam bidang ekonomi". ${ }^{13}$ Dalam perekonomian yang telah maju, para produsen tidak menjual hasil produksi mereka secara langsung kepada pemakai akhir.
Banyak cara yang dapat digunakan untuk mendistribusikan barang kepada pembeli. Dalam hal pendistribusian ini harus memiliki identitas produsen karena akan memudahkan konsumen menuntut ganti rugi, konsumen yang dirugikan akibat penggunaan produk tidak begitu kesulitan dalam menemukan kepada siapa tuntutan diajukan, karena banyak pihak yang dapat digugat, namun akan lebih baik lagi seandainya UUPK (Undang-Undang Perlindungan Konsumen) tersebut memberikan rincian sebagaimana dalam directive, sehingga konsumen dapat lebih mudah lagi untuk menentukan kepada siapa ia akan mengajukan tuntutan jika ia dirugikan akibat penggunaan produk. $^{14}$ Sebuah perusahaan mungkin mendistribusikan barangnya secara langsung kepada konsumen meskipun jumlahnya cukup besar, sedangkan perusahaan lain mendistribusikan produknya lewat perantara.

Tidak sedikit perusahaan yang menggunakan beberapa kombinasi saluran distribusi untuk mencapai segmen pasar yang berbeda. Proses penyaluran produk sampai kepada pembeli akhir dapat panjang ataupun pendek, sesuai dengan kebijaksanaan

12 David Sukardi Kodrat, Manajemen Distribusi... op.cit., hlm. 22.

13 Undang-Undang Nomor 5 Tahun 1999 tentang Larangan Praktek Monopoli dan Persaingan Usaha Tidak Sehat.

14 Ahmad Miru, Prinsip-prinsip Perlindungan Hukum Bagi Konsumen di Indonesia, Disertasi pada Program Pascasarjana Universitas Airlangga, (Surabaya: UNAIR, 2000), hlm. 31. 
saluran distribusi yang dianut oleh masing-masing perusahaan. Ada beberapa alternatif jenis saluran yang dapat digunakan berdasarkan jenis produk dan segmen pasar, yaitu:
a. Saluran distribusi barang konsumsi;
b. Saluran ditribusi barang industri;
c. Saluran distribusi jiwa.

Dalam lingkaran distribusi gas elpiji $3 \mathrm{~kg}$ (tiga kilogram) khususnya dan untuk ukuran lainnya posisi agen menempati posisi kunci distribusi.

\section{Pendistribusian Gas Elpiji Di PT. Dianmas Putra Sejahtera}

Agen elpiji merupakan badan usaha yang berbadan hukum PT dan merupakan mitra pertamina yang menjual elpiji baik dalam kemasan tabung ataupun curah ke konsumen. Himpunan Wiraswasta Nasional Minyak dan Gas Bumi (Hiswana Migas) mengakui jika ada penerapan sistem rayon dalam penyaluran elpiji bersubsidi $3 \mathrm{~kg}$ (tiga kilogram). Ketua DPD III Hiswana migas wilayah Cianjur Bapak Suryadi menjelaskan sistem rayonisasi adalah pembatasan setiap daerah dalam penggunaan elpiji bersubsidi $3 \mathrm{~kg}$ (tiga kilogram), jadi satu daerah tidak bisa menggunakan jatah daerah lain, dikarenakan kebijakan yang ada sekarang dengan istilah rayonisasi jadi tidak boleh saling menyeberang, sistem ini diterapkan karena adanya tuntutan dari Badan Pemeriksa Keuangan (BPK). Dalam hal ini PT. Dianmas Putra Sejahtera mendistribusikan gas elpiji kepada sub agen ataupun pangkalanpangkalan yang sudah melakukan perjanjian kontrak sebelumnya. Dalam penggunaan kontrak baku/klausula baku, kebebasan untuk melakukan kontrak serta pemberian kesepakatan terhadap kontrak tersebut tidak dilakukan sebebas dengan perjanjian yang dilakukan secara langsung dengan melibatkan para pihak dalam menegosiasikan klausula perjanjian. ${ }^{15}$ Dalam hukum perjanjian, istilah klausula baku disebut juga klausula eksonerasi, dalam Undang-Undang Nomor 8 Tahun 1999 tentang Perlindungan Konsumen juga dijelaskan bahwa yang dimaksud dengan klausula baku adalah setiap aturan atau ketentuan dan syarat-syarat yang telah dipersiapkan dan ditetapkan terlebih dahulu secara sepihak oleh pelaku usaha yang dituangkan dalam suatu dokumen dan/atau perjanjian yang mengikat dan wajib dipenuhi oleh konsumen. Klausula baku ini banyak digunakan dalam setiap perjanjian yang bersifat sepihak, dan dalam bahasa umum sering disebut sebagai "disclamer",

\footnotetext{
15 Ahmadi Miru, Sutarman Yodo, Hukum Perlindungan Konsumen, Edisi Revisi, (Jakarta: Raja Grafindo Persada, 2015), hlm. 19.
} 
yang bertujuan untuk melindungi pihak yang memberikan suatu jasa tertentu. ${ }^{16}$ Tidak mudah menciptakan hubungan kerja yang demikian, walaupun para pihak yang terlibat dalam hubungan industrial mempunyai tujuan yang sama tetapi pada prinsipnya memiliki kepentingan yang berbeda dan kepentingan yang berbeda tersebut susah dirukunkan. ${ }^{17}$ Dalam hal ini, agen akan mendistribusikan gas elpiji kepada setiap sub agen berdasarkan kontrak masingmasing, di dalam kontrak antara agen dan sub agen tersebut berisikan berapa jumlah barang/tabung gas elpiji yang harus didistribusikan ke setiap sub agen tersebut, diadakannya suatu kontrak perjanjian karena diantara produsen/ pelaku usaha maupun konsumen harus memiliki perlindungan hukum masingmasing.

Undang-Undang Nomor 8 Tahun 1999 tentang Perlindungan Konsumen (UUPK) menyebutkan bahwa perlindungan konsumen berasaskan manfaat, keadilan, keseimbangan, keamanan dan keselamatan konsumen serta kepastian hukum. Dengan adanya asas perlindungan konsumen yang relevan dalam pembangunan nasional diharapkan dapat terciptanya keseimbangan antara konsumen dan pelaku usaha sehingga mendorong pelaku usaha yang jujur dan bertanggungjawab dalam menjalankan usahanya. Mengenai hak konsumen yang diatur dalam UUPK menyebutkan bahwa salah satu hak konsumen adalah hak untuk diperlakukan atau dilayani secara benar dan jujur serta tidak diskriminatif, pada realita dalam hal penentuan harga gas elpiji terdapat ketidaksesuaian dengan aturan.

Menurut Hans W. Micklitz, dalam perlindungan konsumen secara garis besar dapat ditempuh dua model kebijakan. Pertama, kebijakan yang bersifat komplementer, yaitu kebijakan yang mewajibkan melakukan pelaku usaha memberikan informasi yang memadai kepada konsumen (hak atas informasi). Kedua, kebijakan kompensatoris, yaitu kewajiban yang berisikan perlindungan terhadap kepentingan ekonomi konsumen (hak atas keamanan dan kesehatan).

Konsumen tidak cukup dilindungi hanya berdasarkan kebijakan komplementer (memberikan informasi) saja, tetapi juga harus ditindaklanjuti dengan kebijakan kompensatoris guna meminimalisasi resiko yang ditanggung konsumen. ${ }^{18}$

16 Jonaedi Efendi, dkk, Kamus Istilah... op.cit., hlm. 232.

17 Ahmad Hunaeni Zulkarnaen, "Perlindungan Hukum terhadap Pekerja dalam Pelaksanaan Hubungan Industrial," PADJADJARAN Jurnal Ilmu Hukum (Journal of Law) 3 No. 2 (2017), hlm. 418.

18 Zulham, Hukum Perlindungan Konsumen, Edisi Revisi, (Jakarta: Prenada Media Group, 2016, hlm. 50. 
Perlindungan konsumen tidak saja terhadap barang-barang berkualitas rendah, akan tetapi juga terhadap barangbarang yang membahayakan kehidupan masyarakat. ${ }^{19}$ Oleh karenanya dalam hal ini sangat penting perlindungan hukum bagi konsumen maupun pelaku usaha, karena hukum mempunyai tujuan untuk mewujudkan keadilan, kemanfaatan, dan kepastian hukum. ${ }^{20}$ Dalam pelaksanaan pendistribusian gas elpiji yang menggunakan penerapan sistem rayon per-wilayah, maka PT. Dianmas Putra Sejahtera mendistribusikan gas elpiji sesuai rayon yang ditentukan yaitu rayonIX-MOR111 untuk wilayah Cianjur, adapun sub agen yang didistribusi oleh PT. Dianmas Putra Sejahtera terletak di beberapa daerah di Kabupaten Cianjur, diantaranya: Cipanas, Cikalong, Selajambe, Ciangsana, Cilaku, Lio, Tanjung, Sindanglaka, Cidaun, Pasir Sembung, Bababkansari, dari semua sub agen tidak semua yang melakukan distribusi langsung dari agen ke sub agen, ada beberapa sub agen yang mengambil barang langsung ke gudang PT. Dianmas Putra Sejahtera, karena hambatan waktu maupun jarak tempuh, tetapi tidak keluar dari perjanjian awal yang tertulis pada surat kontrak antara sub agen dan agen. Semua sub agen/ pangkalan dapat menerima barangnya jika terlebih dahulu telah melakukan pembayaran secara online menggunakan aplikasi bank mandiri, sehari sebelum pengambilan barang. Tidak hanya sub agen yang menggunakan sistem online begitupun agen nya pun melakukan semua transaksi secara online.

PT. Dianmas Putra Sejahtera memiliki alokasi perbulan rata-rata sebanyak 46080, alokasi tersebut tidak stabil karena melihat berapa hari kerja tiap bulan, tetapi terkadang ada alokasi tambahan disaat tanggal merah yang dinamakan DO fakultatif, itupun tidak setiap bulan ada.Pengambilan barang/ tabung gas elpiji pada PT. Dianmas Putra sejahtera diambil di SPBE yang sudah ditentukan oleh Pertamina.

\section{Penataan Pendistribusian Gas Elpiji $3 \mathrm{Kg}$ (Tiga Kilogram Pada Pangkalan Gas Elpiji Di Kabupaten Cianjur Dikaji Menurut Keputusan Bupati Cianjur Nomor 541.11/KEP.298- PERINDAG/2014}

Jumlah saluran distribusi tertentu yang dipakai oleh para manufaktur adalah sedemikian banyak sehingga seluruh alternatif saluran tersebut tidak mungkin dapat diuraikan. ${ }^{21}$ Dalam

Ibid., hlm. 21.

Ahmad Ali, Menguak Tabir Hukum (Suatu Kajian Filosofis dan Sosiologis) (Jakarta: Gunung Agung, 2002), hlm. 85.

21 Stewart H. Rewoldt, Strategi Distribusi Pemasaran (Jakarta: Bina Aksara, 1987), hlm. 9. 
ekonomi pasar bebas, manufakturing biasanya selalu berarti produksi secara massal untuk dijual ke pelanggan untuk mendapatkan keuntungan. ${ }^{22}$ Teori distribusi sering dimaknai sebagai total pendapatan (income) yang didistribusikan pada setiap individu atau pada seluruh faktor produksi. Teori ini terfokus pada upaya agar berbagai faktor produksi (tanah, buruh dan modal) mendapatkan balasan/harga yang sesuai. ${ }^{23}$ Seperti halnya upah bagi tenaga kerja/buruh, bunga bagi pemilik modal dan sewa bagi tuan tanah, yang memunculkan pendekatan distribusi fungsional dalam memecahkan masalah ketimpang distribusi pendapatan yang terjadi di antara kelas sosial di masyarakat. ${ }^{24}$

Dalam pelaksanaan pendistribusian gas elpiji terdapat proses pendistribusiannya, yaitu dengan cara memanfaatkan teknologi sistem informasi. Saat ini pengembangan dan penerapan teknologi informasi di sektor ekonomi telah berkembang dengan cepat. Pengembangan dan penerapan teknologi informasi yang demikian cepat telah mengakibatkan semakin mudahnya arus informasi yang dapat diperoleh masyarakat, sekaligus memudahkan orang untuk melakukan komunikasi satu sama lain dengan melintas batas ruang dan waktu. Globalisasi dalam dunia ekonomi, khususnya perdagangan. ${ }^{25}$ Sistem informasi tersebut digunakan oleh pihak agen sebanyak pihak yang pertama kali mendistribusikan gas elpiji ke agen-agen kecil lainnya, jadi dengan sistem informasi tersebut akan didapat informasi kemana saja gas elpiji tersebut didistribusikan oleh agen, daerah mana saja yang mengkonsumsi gas elpiji tersebut dan berapa jumlahnya sehingga pertamina dapat mengetahui kebutuhan pasokan gas elpiji pada setiap agen di wilayah tersebut, pada akhirnya diharapkan proses pendistribusian gas akan lebih cepat, akurat agen dapat bekerja secara baik, efektif, dan efisien. ${ }^{26}$ Adapun proses distribusi gas elpiji yaitu sebagai berikut:

22 Wikipedia Ensiklopedia Bebas, Manufaktur, https://id.wikipedia.org/wiki/Manufaktur.

23 Samuelson, dkk, Economics, MacGraw Hill, New York, 2005, dalam Ruslan Abdul Ghofur Noor, Konsep Distribusi Dalam Ekonomi Islam, Dan Format Keadilan Ekonomi Di Indonesia (Yogyakarta: Pustaka Pelajar, 2013), hlm. 57.

24 Ruslan Abdul Ghofur Noor, Konsep Distribusi Dalam Ekonomi Islam, Dan Format Keadilan Ekonomi Di Indonesia (Yogyakarta: Pustaka Pelajar, 2013), hlm. 57.

25 Hetty Hassanah, "Analisis Hukum Tentang Perbuatan Melawan Hukum Dalam Transaksi Bisnis Secara Online (E-Commerce) Berdasarkan Burgerlijke Wetboek Dan Undang-Undang Nomor 11 Tahun 2008 tentang Informasi Dan Transaksi Elektronik." Jurnal Wawasan Yuridika 32 No. 1 (2016), hlm. 38-51.

26 Hilman Ruhyaman, Wawancara Pribadi, PT. Dianmas Putra Sejahtera, Cianjur, 26 Mei 2017. 
a. Proses distribusi diawali dari agen, awalnya agen melakukan penebusan melalui bank, penebusan tersebut sesuai dengan alokasi yang sudah ditentukan oleh pertamina, setelah melakukan penebusan maka akan keluar DO (delivery order) dari Pertamina,

b. Kemudian setelah itu barulah agen melakukan pemesanan atau mengambil tabung gas LPG keSPPBE (Stasiun Pengisian dan Pengangkutan gas Elpiji), ketika pengambilan di SPPBE agen tidak hanya mengambil gas elpiji tetapi agen akan diberikan surat pengantar pengiriman dan stock-out "konsinyasi" atau suatu perjanjian dimana salah satu pihak yang memiliki barang menyerahkan sejumlah barang kepada pihak tertentu untuk dijualkan dengan harga dan syarat yang diatur dalam perjanjian,

c. Selanjutnya setelah pengambilan gas elpiji lalu gas elpiji didistribusikan oleh agen ke setiap pangkalan binaan agen tersebut, sesuai dengan rencana/realisasi penyaluran ke pangkalan LPG 3 (tiga) kilogram), karena setiap harinya penyaluran dari agen ke pangkalan/sub agen itu berbeda, d. Dan setelah gas elpiji didistribusikan kepada pangkalan lalu selanjutnya gas elpiji akan dijual oleh pangkalan kepada konsumen ataupun pengecer, dalam penjualannya pun sub agen/ pangkalan tidak boleh menjual ke pihak industri karena industri harus menggunakan gas elpiji non-subsidi.

Pelaksanaan program konversi minyak tanah ke Liquefied Petroleum Gas agar tepat pada sasaran, tepat harga maupun tepat jumlah, dan terjamin ketersediaan dalam pasokannya tentu perlu pembinaan dan pengawasan pendistribusian elpiji yang melibatkan peran serta pemerintah daerah provinsi dankabupaten/kota.PerananAgendalam pendistribusian gas elpiji mempunyai fungsi sebagai perantara antara PT. Pertamina dengan konsumen dalam penyaluran LPG. Harga jual tertinggi elpiji yang sudah ditetapakan oleh badan hukum yang mengaturnya dengan harapan masyarakat sasaran tidak akan dirugikan dengan permainan harga oleh agen maupun sub agen/pangkalan justru pada harga jual tertinggi elpiji, sub agen/ pangkalan berlomba-lomba menaikan harga jual tersebut dengan berbagai macam alasan, sehingga akan terjadi persaingan yang tidak sehat di level sub agen/pangkalan, ${ }^{27}$ maka dengan harga

27 Faizatul Widad, I Nyoman Pujawan, "Rancangan Konfigurasi Jaringan Logistik Dengan Pendekatan Sistem Tertutup," Jurnal Institut Teknologi 10 November (2012). 
yang melonjak tinggi akan jauh dari tujuan untuk mensejahterakan rakyat.

Fungsi yang terakhir adalah fungsi menyejahterakan, fungsi ini berisi kewenangan pemerintahuntukmengatur Ekonomi kesejahteraan (Walfare Economics), ${ }^{28}$ yang merupakan normative economic, secara jelas membicarakan bagaimana menggunakan sumber daya secara optimal, untuk mewujudkan kehidupan yang layak bagi individu dan masyarakat. ${ }^{29}$ Menurut Amrtya Sen bahwa pembangunan bukan hanya bertumpu pada sumber daya, institusi dan keinginan kuat untuk membangun. Namun, lebih dari itu peran distribusi dalam perdagangan masih membutuhkan pembahasan lebih lanjut, terutama pada sektor informal yang banyak dilakukan masyarakat karena secara riil sektor ini dapat mempersempit ketimpangan ekonomi. Di sini hukum harus menjaga dan menyeimbangkan benturan kepentingan di bidang ekonomi atau antara berbagai kepentingan dalam ruang lingkup ekonomi, seperti kepentingan antara produsen dengan konsumen, antara pemilik perusahaan dengan kepentingan para pekerja. ${ }^{30}$

\section{PENUTUP}

Prosedur pelaksanaan pendistribusian gas elpiji yaitu: terdapat proses pendistribusian dengan cara memanfaatkan teknologi sistem informasi yang bertujuan untuk mendapatkan informasi kemana saja gas elpiji tersebut didistribusikan oleh agen, daerah mana saja yang mengkonsumsi gas elpiji tersebut dan berapa jumlahnya sehingga pertamina dapat mengetahui kebutuhan pasokan gas elpiji pada setiap agen di wilayah tersebut, yang pada akhirnya diharapkan proses pendistribusian gas akan lebih cepat, akurat, agen dapat bekerja secara baik, efektif, dan efisien. Proses pendistribusian tersebut yaitu, diawali dari agen yang kemudian agen akan mendistribusikan gas elpiji kepada pangkalan/sub agen, yang akhirnya sampai ke tangan konsumen ataupun pengecer.

Di dalam hal pendistribusian gas elpiji terhadap sub agen/pangkalan ada faktor-faktor yang menyebabkan penjual menjual gas elpiji melebihi dari Harga Eceran Tertinggi (HET), yaitu karena tidak adanya pengawasan khusus dari badan tertentu, jangkauan jarak maupun kondisi jalan, adanya oknum-oknum

28 Agustina, Bunga. "Kewenangan Pemerintah Dalam Perlindungan Hukum Pelayanan Kesehatan Tradisional Ditinjau Dari Undang-Undang Republik Indonesia Nomor 36 Tahun 2009 tentang Kesehatan." Jurnal Wawasan Yuridika 32 No. 1 (2016), hlm. 82-98.

29 Richard E. Just, dkk, The Welfare Economics and Public Policy, dalam Ruslan Abdul Ghofur Noor, Konsep Distribusi Dalam Ekonomi Islam Dan Format Keadilan Ekonomi Di Indonesia (Yogyakarta: Pustaka Pelajar, 2013), hlm. 12.

30 Munir Fuady, Dinamika Teori Hukum (Bogor: Ghalia Indonesia, 2010), hlm. 17. 
yang tidak bertanggungjawab dan mengikuti harga pasaran yang ada pada daerah setempat.

Selain itu yang menjadi kendala saat pendistribusian gas elpiji, yaitu saluran distribusi ini harus benarbenar dipertimbangkan, dalam hal ini perusahaan atau produsen harus memperhatikan kendala yang dihadapi dalam pendistribusian gas elpiji, diantaranya: terdapat kendala pengiriman karena kurang lancarnya lalu lintas, dan harus mengikuti prosedur yang berlaku saat pengambilan gas elpiji, seperti mengikuti antrian.

\section{DAFTAR PUSTAKA}

Ali, Ahmad. Menguak Tabir Hukum (Suatu Kajian Filosofis dan Sosiologis). Jakarta: Gunung Agung, 2002.

Miru, Ahmadi dan Sutarman Yodo. Hukum Perlindungan Konsumen. Edisi Revisi. Jakarta: Raja Grafindo Persada, 2015.

Endipradja, Firman Tumantara. Hukum Perlindungan Konsumen. Malang: Strata Press, 2016.

Suryanto, Mikael Hang. Sistem Operasional Manajemen Distribusi. Jakarta: Grasindo, 2016.

Nasution, Muhammad Syukri Albani et al., Hukum Dalam Pendekatan Filsafat. Jakarta: Kencana Prenada Media Group, 2016.

Fuady, Munir. Dinamika Teori Hukum. Bogor: Ghalia Indonesia, 2010.

Noor, Ruslan Abdul Ghofur. Konsep Distribusi Dalam Ekonomi Islam dan Format Keadilan Ekonomi di Indonesia. Yogyakarta: Pustaka Pelajar, 2013.

Rewoldt, Stewart H. Strategi Distribusi Pemasaran. Jakarta: Bina Aksara, 1987.

Zulham, Hukum Perlindungan Konsumen. Edisi Revisi. Jakarta: Prenada Media Group, 2016. 
Indonesia. Undang-Undang Nomor 8 Tahun 1999 tentang Perlindungan Konsumen.

Indonesia. Undang-Undang Nomor 5 Tahun 1999 tentang Larangan Praktek Monopoli dan Persaingan Usaha Tidak Sehat.

Keputusan Bupati Cianjur Nomor 541.11/ Kep.298-Perindag/2014 tentang Perubahan Kedua atas Keputusan Bupati Cianjur Nomor 541.11/ KEP.124-PE/2012 tentang Penetapan Harga Jual Eceran Tertinggi Liquified Petroleum Gas Tabung Ukuran $3 \mathrm{Kg}$ (Tiga Kilogram) Untuk Keperluan Rumah Tangga dan Usaha Mikro di Kabupaten Cianjur.

Surat Pengusul DPR RI Nomor: 05/ LEGNAS/KES.BANG/XI/98 tanggal 20 November 1998.

Agustina, Bunga. "Kewenangan Pemerintah Dalam Perlindungan Hukum Pelayanan Kesehatan Tradisional Ditinjau Dari Undang-Undang Republik Indonesia Nomor 36 Tahun 2009 tentang Kesehatan." Jurnal Wawasan Yuridika 32 No. 1 (2016).

Zulkarnaen, Ahmad Hunaeni. "Perlindungan Hukum terhadap Pekerja dalam Pelaksanaan Hubungan Industrial". PADJADJARAN Jurnal Ilmu Hukum (Journal of Law) 3 No. 2 (2017).
Miru, Ahmad. Prinsip-prinsip Perlindungan Hukum Bagi Konsumen di Indonesia. Disertasi Pada Program Pascasarjana Universitas Airlangga. (Surabaya: UNAIR, 2000).

Purnomo, Edy. "Pengertian Distribusi Secara Umum dan Menurut Para Ahli." https://vauzidotnet. wordpress.com/2014/03/07/ pengertiandistribusi-secara-umumdan-menurut-para-ahli/, 2014.

Widad, Faizatul dan I Nyoman Pujawan. "Rancangan Konfigurasi Jaringan Logistik Dengan Pendekatan Sistem Tertutup." Jurnal Institut Teknologi 10 November (2012).

Hassanah, Hetty. "Analisis Hukum Tentang Perbuatan Melawan Hukum Dalam Transaksi Bisnis Secara Online (E-Commerce) Berdasarkan Burgerlijke Wetboek Dan UndangUndang Nomor 11 Tahun 2008 tentang Informasi Dan Transaksi Elektronik." Jurnal Wawasan Yuridika 32 No. 1 (2016).

Ruhyaman, Hilman. Wawancara Pribadi, PT. Dianmas Putra Sejahetera, Cianjur, 25 Mei 2017.

Efendi, Jonaedi et al., Kamus Istilah Hukum Populer. Surabaya: Kencana, 2016.

Efendi, Saladdin Wirawan. "Analisis Usaha Bisnis Distribusi Gas Elpiji 3 
Kg," Jurnal STIM Amkop (Palembang, 2012).

Novata, Yuni Minar. "Distribusi Untuk

Kegiatan Usaha." Jurnal Politeknik

(Bandung 2014). 